\title{
Effect of drying, pelliculation and storage on the physiological quality of eggplant seeds ${ }^{1}$
}

\author{
Natassia Zamariola2*, João Almir Oliveira², Luiz Antônio Augusto Gomes², \\ Michelle Fonseca Jácome ${ }^{2}$, Leandro Vilela Reis ${ }^{2}$
}

\begin{abstract}
The use of methods and technologies such as drying and film coating can bring significant contributions to the farmer. This experiment was conducted in order to evaluate the effect of drying and film coating on the physiological quality of eggplant seeds during storage. Hybrid seeds UGA MS1 produced by the company Hortiagro - Ijaci, MG were used. Seeds were subjected to two types of drying: slow (room temperature) and quick (oven with forced air circulation at $35{ }^{\circ} \mathrm{C}$ ). The chemical treatment was performed with the Captan product at a dose of 250 grams per 100 kilograms of seed and for the recoating were used three doses of polymer: $\left(0,3\right.$ and $6 \mathrm{~mL} \cdot \mathrm{kg}^{-1}$ of seeds). The physiological quality of seeds was evaluated every three months until reaching the period of nine months using germination test, seedling emergence test and seedling establishment. There is a reduction of physiological seed quality during the storage. The slow drying of eggplant seeds results in better quality seeds. The use of polymer reduces the germination percentage, germination speed index and the percentage of seedling emergence.
\end{abstract}

Index terms: Solanum melongena, vigor, film coating.

\section{Efeito da secagem, peliculização e armazenamento na qualidade fisiológica de sementes de berinjela}

\begin{abstract}
RESUMO - O uso de métodos e tecnologias como secagem e recobrimento podem trazer significativas contribuições para o agricultor. Com o objetivo de avaliar o efeito da secagem, peliculização e armazenamento na qualidade fisiológica de sementes de berinjela, conduziu-se esse experimento. Foram utilizadas sementes híbridas UGA MS1 produzidas pela empresa Hortiagro - Ijaci, MG. As sementes foram submetidas a dois tipos de secagem: lenta (temperatura ambiente) e rápida (estufa de circulação forçada de ar a $35^{\circ} \mathrm{C}$ ). O tratamento químico foi realizado com o produto Captan na dose de 250 gramas por 100 quilogramas de sementes e para o recobrimento foram utilizadas três doses de polímero, 0,3 e $6 \mathrm{~mL} \cdot \mathrm{kg}^{-1}$ de semente. A qualidade fisiológica das sementes foi avaliada a cada três meses até atingir o período de nove meses utilizando os testes de germinação, emergência de plântulas e estabelecimento de mudas. Ocorre redução da qualidade fisiológica das sementes ao longo do armazenamento. A secagem lenta das sementes de berinjela resulta em sementes de melhor qualidade. O uso do polímero reduz a percentagem de germinação, índice de velocidade de germinação e a percentagem de emergência das plântulas.
\end{abstract}

Termos para indexação: Solanum melongena, vigor, recobrimento de sementes.

\section{Introduction}

Eggplant (Solanum melongena L.) has always been considered a vegetable of secondary importance. However, due to its qualities and benefits to human health, this scenario has been changing. The consumption of this vegetable spread in Brazil due to its nutritional properties and medicinal value, and to its being a source of vitamins (A, B and C) and minerals, especially magnesium, potassium and sulfur, in addition to there being reports of its use in the treatment of asthma, diabetes, cholera, bronchitis and cholesterol control (Ribeiro, 2007).

Within the vegetable production chain, the production step of seedling directly influences the final performance of the plant (Campanharo et al., 2006), as healthy and well-formed seedlings can increase production as well as anticipate harvest (Costa et al., 2012). Thus, high quality seeds for forming these seedlings and conditions that allow maximum germination in

\footnotetext{
${ }^{1}$ Submitted on 01/28/2014. Accepted for pubblication on 04/30/2014.

${ }^{2}$ Departamento de Agricultura, UFLA, Caixa Postal 3037, 37200-000 - Lavras, MG, Brasil.

*Corresponding author <natassiazamariola@yahoo.com.br>
} 
the shortest possible time with maximum uniformity of seedlings are essential to obtain a high yield (Nascimento, 2005a). The production of high quality vegetable seeds requires special techniques, since they have high added value and their care extends from the choice of the area, soil preparation, sowing, harvesting, drying, processing and storage (Nascimento, 2005b). At the ideal moment for harvest, seeds of fleshy fruits (such as eggplant) have high humidity, making drying an essential process for the production of high quality seeds. However, improper drying can cause damage to the seeds, such as reduced storage potential (Silva et al., 2011) and rupture of the membrane (Chen and Burris, 1990), in addition to contributing to the occurrence of secondary seed dormancy (Wood et al., 2000).

In the seed production process, the storage step is critical for success in the system, since in inadequate conditions all the development work in the field and all the processing may be lost (Caldwell et al., 2005). Several factors influence the maintenance of seed viability during storage, such as humidity, temperature, gas exchange, maturity, infestation by fungi and insects (Caldwell et al., 2005).

As a strategy to overcome the problems caused by microorganisms, producers have been favorable to chemical seed treatment. However, concerns about the chemicals used allowed the incorporation of a new technique in agronomy that has been widely used by the vegetable seed industry (Medeiros et al., 2006): film coating. This technology is designed primarily to enable the incorporation of other materials such as fungicides, growth regulators and micronutrients (Oliveira et al., 2006), reduce human exposure to toxic chemicals added to the seeds (Taylor et al., 1998), allow easy identification of treated seeds (Ni and Biddle, 2001), contribute for the proper amount of active ingredients to be applied is adhered to the surface of the seeds guaranteeing their performance (Kunkur et al., 2007), in addition to providing seeds with good appearance, color and adhesion (Bays et al., 2007).

Few studies have been conducted to evaluate the effects of the drying process and the use of polymers in stored seeds. Thus, the objective of this research was to evaluate the effect of drying and the use of polymer in the physiological quality of eggplant seeds during storage.

\section{Materials and Methods}

The experiment was conducted in the land of HortiAgro Seeds Ltda, located near the town of Ijaci - MG, Brazil, and in the Laboratório Central de Sementes da Universidade Federal de Lavras (UFLA) from February 2012 through September 2013.

The eggplant hybrid UGA MS1, produced in-house, was used. Seeds were sown in trays containing Plantimax substrate in a greenhouse. Thirty days after sowing, the seedlings were transplanted to the field at a spacing of $0.80 \times 0.50 \mathrm{~m}$. The fruits were harvested at 120 days after anthesis. The seeds were removed mechanically and subsequently washed with water. They were then subjected to two drying speeds: slow, carried out at room temperature with ventilation system only; and fast, held in circulating air oven at $35^{\circ} \mathrm{C}$. In both processes the water content of the seeds was reduced to $7 \%$. Seeds subjected to rapid drying took 8 hours to reach the desired degree of moisture, while seeds slowly dried took three times that long to achieve the same water content. After drying, the seeds were divided into three groups, differentiating the doses of the polymer (zero, $3 \mathrm{~mL} . \mathrm{Kg}^{-1}$ seeds which is the dosage recommended by the manufacturer, and double dose, $6 \mathrm{~mL} \cdot \mathrm{Kg}^{-1}$ of seeds). All seeds were treated with Captan fungicide at a dosage of 250 grams of product per $100 \mathrm{~kg}$ of seed, added to the polymer or water, when the polymer is not used.

After treatment, the seeds were dried at $30{ }^{\circ} \mathrm{C}$ until reaching approximately $7 \%$ moisture, and then were placed in plastic laminated packaging and stored under ambient conditions without controlled temperature and relative humidity for a period of nine months. The physiological and sanitary quality of seeds of each treatment was assessed every three months using the following tests:

Germination: four replicates were used of 50 seeds sown on two sheets of blotting paper, moistened with water at a ratio of 2.5 times the weight of dry substrate in gerbox plastic boxes, under alternating light and temperature regime, $20^{\circ} \mathrm{C} / 16 \mathrm{~h}$ in the dark and $30{ }^{\circ} \mathrm{C} / 8 \mathrm{~h}$ in the presence of light. Counts were made at seven and 14 days after sowing, and the percentage of normal seedlings was counted (Brasil, 2009). Germination speed index: held in conjunction with the germination test, with daily counts from the first root protrusion, calculating the germination speed index according to the formula proposed by Maguire (1962). Seedling emergence: four replicates of 50 seeds were sown in plastic boxes containing soil and sand (2:1 $\mathrm{v} / \mathrm{v}$ ) moistened ( $60 \%$ of the retention capacity of the substrate) and maintained in a growth chamber under alternating light and dark regime $(12 \mathrm{~h})$ at $25^{\circ} \mathrm{C}$. The final stand was obtained at 21 days after sowing, by counting the percentage of normal seedlings emerged. Emergence speed index: held in conjunction with the emergence test. Counting of seedlings was initiated after emergence of the first seedling, with daily counts performed until its stabilization (21 days after sowing). The index was calculated using the Maguire formula (1962). Seedling establishment: four replicates of 50 seeds were sown in polystyrene trays containing vermiculite and Plantimax commercial substrate, kept in a greenhouse with plastic cover and screened sides in the seed producing company HortiAgro. 
At 30 days after sowing, the percentage of favorable seedlings to be transplanted was determined (number of leaves higher than five, healthy, well-formed - according to criteria used in the company). Experimental design and statistical analysis: we used a completely randomized design with four replications, in a $2 \times 3 \times 4$ factorial scheme, the first factor being drying methods (slow and fast), the second being the three polymer doses ( 0 , 100 and $200 \%$ of the recommended dose), and the third factor being the four storage periods (0, 3, 6 and 9 months). The data relating to the period factor were subjected to regression analysis. The averages obtained in the other factors (drying and polymer doses) were compared by the Scott-Knott test at $5 \%$ probability. For polymer doses, no regression study was performed, since the objective was to determine whether the polymer dose recommended by the manufacturer and the double dose can cause any negative effect on seed quality.

\section{Results and Discussion}

There was a significant effect of the interaction between the drying speeds, polymer doses and periods of storage for germination, emergence, emergence speed index and germination speed index tests. For the establishment of seedlings there was an isolated effect of drying speeds and periods of storage.

There was a reduction of seed germination during storage for both drying rates, being more evident in seeds exposed to rapid drying (Figure 1), not differing, however, from the seeds dried slowly and treated with twice the recommended dose of polymer (Table 1A). França et al. (2013) evaluated different drying methods (sol/24 h; sol/48 h; $32{ }^{\circ} \mathrm{C} / 24 \mathrm{~h} ; 32{ }^{\circ} \mathrm{C} / 48 \mathrm{~h} ; 38$ ${ }^{\circ} \mathrm{C} / 24 \mathrm{~h} ; 38^{\circ} \mathrm{C} / 48 \mathrm{~h}$; sol $/ 24 \mathrm{~h}+32^{\circ} \mathrm{C} / 24 \mathrm{~h} ;$ sol $/ 24 \mathrm{~h}+38^{\circ} \mathrm{C} / 24$ h e $32{ }^{\circ} \mathrm{C} / 24 \mathrm{~h}+38^{\circ} \mathrm{C} / 24 \mathrm{~h}$ ) in eggplant seeds at time zero and after six months of storage, not finding difference between the germination of various drying methods, even after the storage period. As for the film coating, it was observed that the use of polymer with double the recommended dose may negatively interfere with seeds dried quickly at zero and six months of storage (Table 1A and Figure 1). There was a reduction in the germination of seeds dried slowly, stored for six to nine months and treated with the recommended dose and double the polymer, respectively (Table 1A and Figure 1). According to Pires et al. (2004), the polymers have allowed increased penetration and fixation of the active product, thus improving its distribution to seeds. It should be emphasized, however, that by increasing the fixation of the active products, there may be a toxic effect of products incorporated in these seeds, reducing the germination. Bays et al. (2007), evaluating the physiological quality of soybean seeds after fungicide application, micronutrients $(\mathrm{CoMoB})$ and covering with commercial polymer, observed that the highest dose of the micronutrient ( $4 \mathrm{~mL} \cdot \mathrm{kg}^{-1}$ of seeds) is phytotoxic when seeds are coated with fungicide and polymer.

Table 1. Percentage of germination (A) and emergence (B), emergence speed index (C) and germination speed index (D) of eggplant seeds subjected to slow drying (SL) and quick drying (SR) and treated with different doses of the polymer throughout the storage period.

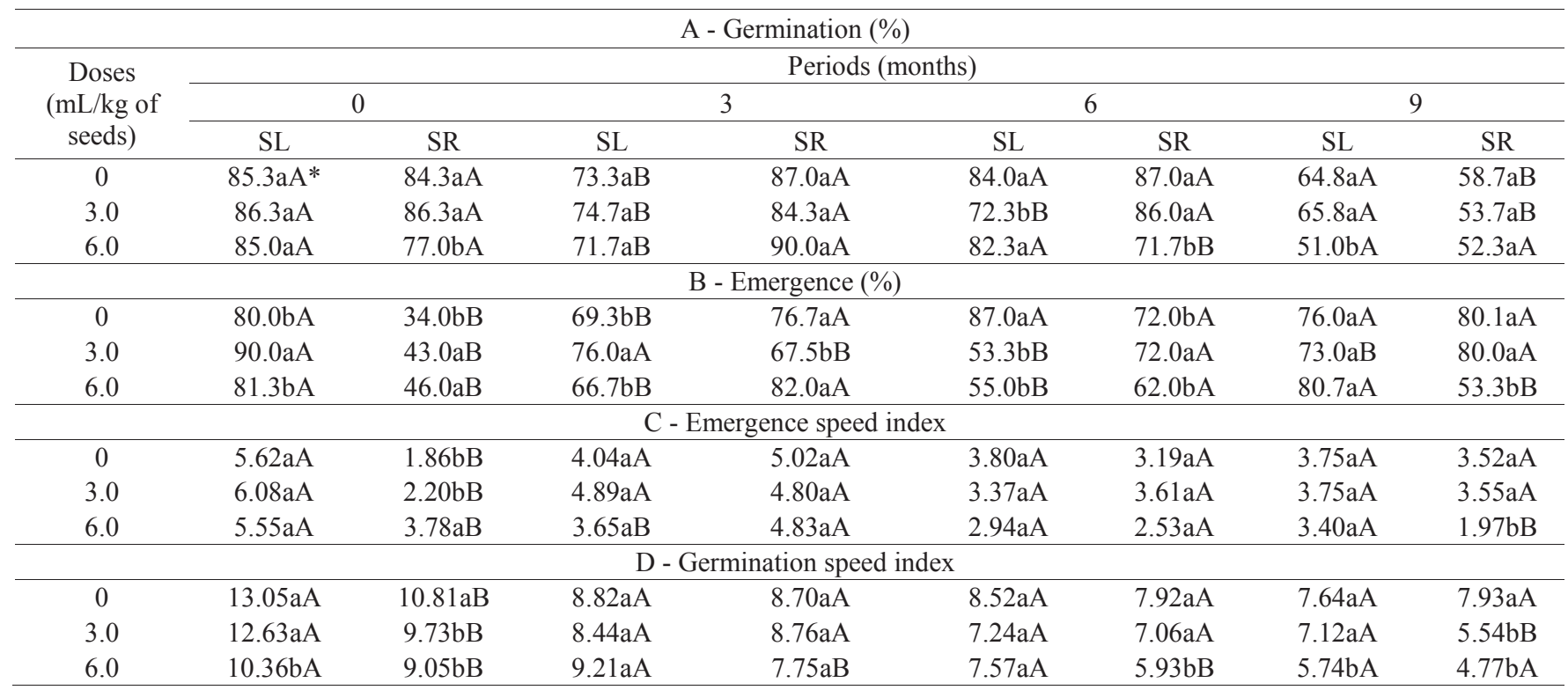

*Means followed by the same lowercase letter in the columns and the same capital letter in the rows for each storage period do not differ by the Scott-Knott test at $5 \%$ probability. 
Regarding the effect of drying rates in eggplant seeds, it was observed by the results of the emergence (Table 1B and Figure 2), emergence speed index (Table 1C and Figure 3) and germination speed index (Table 1D and Figure 4) tests that in the seeds dried quickly there was the induction of secondary dormancy caused by their exposure to elevated

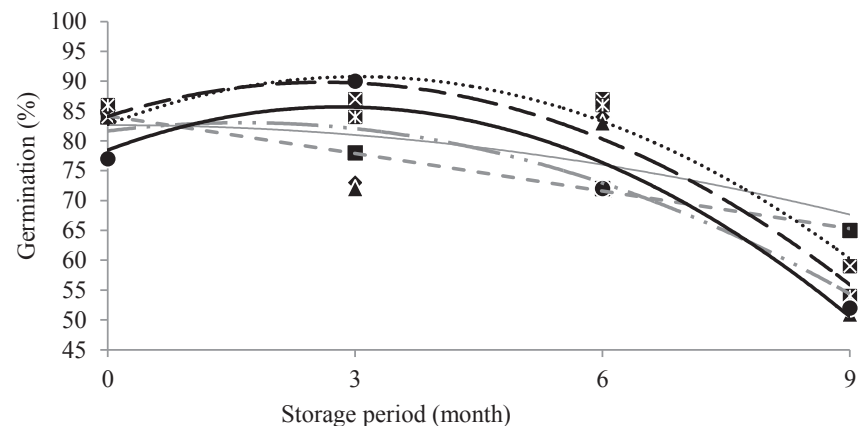

- Slow drying dose zero \ Slow drying dose three \ Slow drying dose six $\boldsymbol{\nabla}$ Quick drying dose zero $\boldsymbol{\otimes}$ Quick drying dose three $\bullet$ Quick drying dose six

\begin{tabular}{lll}
\hline \multicolumn{1}{c}{ Treatment } & \multicolumn{1}{c}{ Equations } & $\mathrm{R}^{2}$ \\
\hline Slow drying dose zero & $\mathrm{y}=-0.1861 \mathrm{x}^{2}+0.0117 \mathrm{x}+82.635$ & $0.4886^{*}$ \\
Slow drying dose three & $\mathrm{y}=-2.1 \mathrm{x}+84.2$ & $0.9290^{*}$ \\
Slow drying dose six & $\mathrm{y}=-0.5278 \mathrm{x}^{2}+1.7167 \mathrm{x}+81.65$ & $0.6920^{*}$ \\
Quick drying dose zero & $\mathrm{y}=-0.8611 \mathrm{x}^{2}+5.25 \mathrm{x}+82.75$ & $0.9435^{*}$ \\
Quick drying dose three & $\mathrm{y}=-0.8333 \mathrm{x}^{2}+4.3667 \mathrm{x}+84.1$ & $0.9023^{*}$ \\
Quick drying dose six & $\mathrm{y}=-0.9167 \mathrm{x}^{2}+5.15 \mathrm{x}+78.4 .5$ & $0.9437^{*}$
\end{tabular}

Figure 1. Equations of regression of the percentage of germination of eggplant seeds under different drying speeds and doses of polymer throughout the storage period.

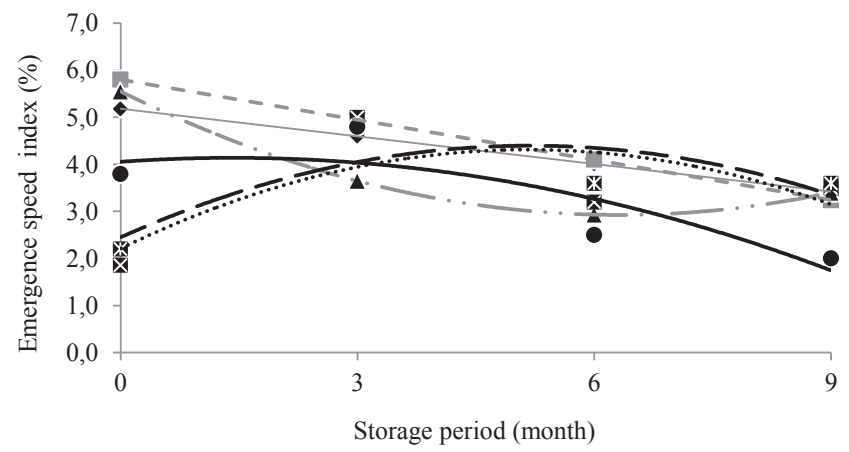

- Slow drying dose zero $\boldsymbol{\otimes}$ Quick drying dose zero

- Slow drying dose three $\quad$ S Slow drying dose six « Quick drying dose three $\bullet$ Quick drying dose six

\begin{tabular}{lll}
\hline \multicolumn{1}{c}{ Treatment } & Equations & $\mathrm{R}^{2}$ \\
\hline Slow drying dose zero & $\mathrm{y}=-0.1957 \mathrm{x}+5.183$ & $0.7260^{*}$ \\
Slow drying dose three & $\mathrm{y}=-0.2843 \mathrm{x}+5.802$ & $0.8063^{*}$ \\
Slow drying dose six & $\mathrm{y}=0.0658 \mathrm{x}^{2}-0.8315 \mathrm{x}+5.5505$ & $1.0000^{*}$ \\
Quick drying dose zero & $\mathrm{y}=-0.0789 \mathrm{x}^{2}+0.814 \mathrm{x}+2.212$ & $0.5025^{*}$ \\
Quick drying dose three & $\mathrm{y}=-0.0722 \mathrm{x}^{2}+0.75 \mathrm{x}+2.45$ & $0.6313^{*}$ \\
Quick drying dose six & $\mathrm{y}=-0.0417 \mathrm{x}^{2}+0.1183 \mathrm{x}+4.055$ & $0.7306^{*}$ \\
\hline
\end{tabular}

Figure 3. Equations of regression of the emergence speed index of eggplant seeds under different speeds of drying and doses of polymer throughout the storage period. temperatures, and that was overcome after three months of storage. According to Wood et al. (2000), one of the problems caused by the drying process is the occurrence of secondary dormancy. However, the occurrence of such dormancy is dependent on the drying temperature used and also the species studied.

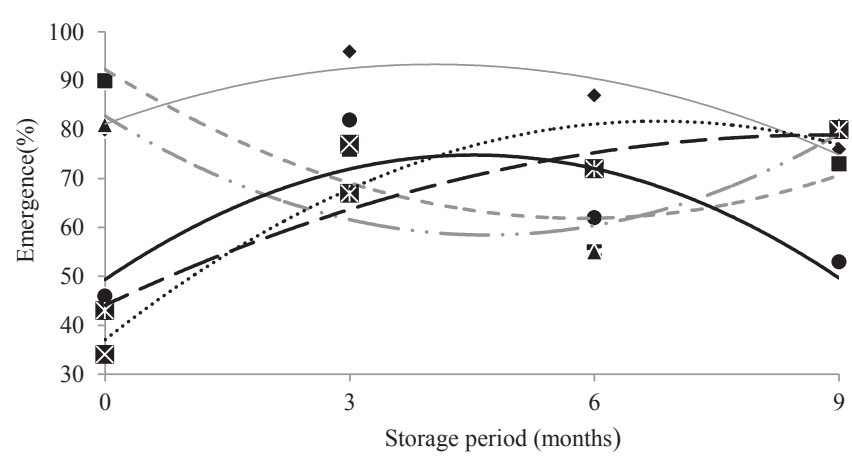

- Slow drying dose zero $\quad$ Slow drying dose three $\quad$ Slow drying dose six $\boldsymbol{\otimes}$ Quick drying dose zero $\bullet$ Quick drying dose three $\mathbb{*}$ Quick drying dose six

\begin{tabular}{llc}
\hline \multicolumn{1}{c}{ Treatment } & Equations & $\mathrm{R}^{2}$ \\
\hline Slow drying dose zero & $\mathrm{y}=-0.75 \mathrm{x}^{2}+6.05 \mathrm{x}+81.15$ & $0.8854^{*}$ \\
Slow drying dose three & $\mathrm{y}=0.8889 \mathrm{x}^{2}-10.4 \mathrm{x}+92.3$ & $0.8296^{*}$ \\
Slow drying dose six & $\mathrm{y}=1.1111 \mathrm{x}^{2}-10.4 \mathrm{x}+82.8$ & $0.8627 *$ \\
Quick drying dose zero & $\mathrm{y}=0.9722 \mathrm{x}^{2}+13.183 \mathrm{x}+37.05$ & $0.8649^{*}$ \\
Quick drying dose three & $\mathrm{y}=-1.25 \mathrm{x}^{2}+11.283 \mathrm{x}+49.35$ & $0.6928^{*}$ \\
Quick drying dose six & $\mathrm{y}=-0.4444 \mathrm{x}^{2}+7.8667 \mathrm{x}+44.1$ & $0.9682^{*}$ \\
\hline
\end{tabular}

Figure 2. Equations of regression of the percentage of emergence of seeds eggplant under different speeds of drying and doses of polymer throughout the storage period.

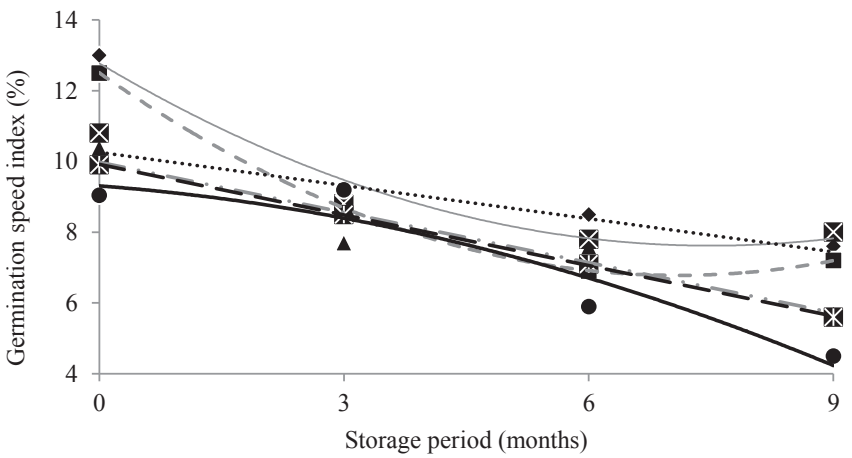

- Slow drying dose zero $\quad$ Slow drying dose three $\quad$ Slow drying dose six $\boldsymbol{X}$ Quick drying dose zero $\mathbb{\boldsymbol { X }}$ Quick drying dose three $\bullet$ Quick drying dose six:

\begin{tabular}{llc}
\hline \multicolumn{1}{c}{ Treatment } & Equations & $\mathrm{R}^{2}$ \\
\hline Slow drying dose zero & $\mathrm{y}=0.0917 \mathrm{x}^{2}-1.375 \mathrm{x}+12.775$ & $0.9416^{*}$ \\
Slow drying dose three & $\mathrm{y}=0.1139 \mathrm{x}^{2}-1.615 \mathrm{x}+12.505$ & $0.9908^{*}$ \\
Slow drying dose six & $\mathrm{y}=--0.4733 \mathrm{x}+9.98$ & $0.8994^{*}$ \\
Quick drying dose zero & $\mathrm{y}=-0.3133 \mathrm{x}+10.26$ & $0.7847^{*}$ \\
Quick drying dose three & $\mathrm{y}=-0.4767 \mathrm{x}+9.92$ & $0.9882^{*}$ \\
Quick drying dose six & $\mathrm{y}=-0.0433 \mathrm{x}^{2}-0.174 \mathrm{x}+9.308$ & $0.9122^{*}$ \\
\hline
\end{tabular}

Figure 4. Equations of regression of germination speed index of eggplant seeds under different drying speeds and polymer doses throughout the storage period. 
The use of polymers in the recommended dose caused a positive effect on the germination percentage of the seeds throughout the storage period in most treatments. However, this increased dose can reduce seed quality depending on the time and speed of drying.

It was observed that film coating does not interfere with the emergence speed index during storage (Table 1C and Figure 3). Similar results were found by Holbig et al. (2010) working with carrot seeds, comparing the use of polymer, polymer with fungicide, only fungicide and a witness, where the film coated seeds presented similar averages of those of seeds without treatment, but both were lower than the seeds treated with polymer + fungicide. As for the germination speed index (Table 1D and Figure 4), there was a reduction in averages when applying the polymer on most of the treatments evaluated, with reduction not occurring only in slow drying at 3 and 6 months of storage and in quick drying after 3 months of storage. Similar results were observed by Holbig et al. (2011) in onion seeds, comparing the use of polymer, polymer with fungicide, only fungicide and a witness. According to these authors, the coated seeds showed slower germination than uncoated seeds.

There was an influence of drying speeds and periods of storage in the establishment of seedlings, and the best results $(51 \%)$ were obtained for seeds dried slowly in relation to treatments with quick drying (46\%).

As for storage, a drastic reduction of seed quality throughout the period, starting quality loss within the first three months of storage, was observed (Figure 5). Similar results have also been found by Contreiras Rodrigues et al. (2011), but with osmoconditioned parsley seeds, who found that the maximum storage time was 90 days, being that degradation began already at the first month of storage. According Sinicio et al. (2009), in the post-harvest stage, storage is one of the steps that most interferes with the quality of the seeds, as there are numerous factors involved.

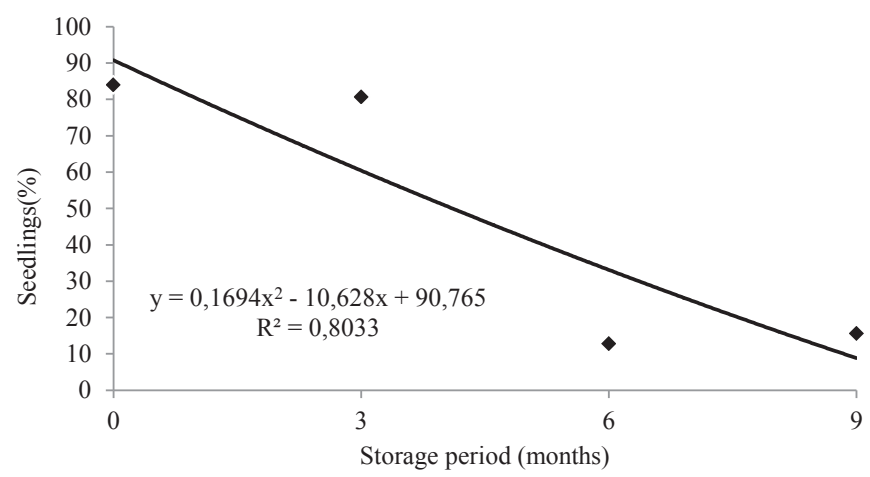

Figure 5. Equation of regression of the percentage of eggplant seedlings obtained from seeds submitted to different storage periods.

\section{Conclusions}

Film coating reduces the germination percentage, germination speed index and the percentage of emergence of eggplant seedlings regardless of the drying speed.

Slow drying results in better quality eggplant seeds.

There is a reduction of physiological seed quality during storage.

The fast drying induces secondary dormancy in seeds, which is overcome throughout the storage period.

\section{References}

BAYS, R.; BAUDET, L.; HENNING, A.A.; LUCCA FILHO, O. Recobrimento de soja com micronutrientes, fungicida e polímero. Revista Brasileira de Sementes, v.29, n.2, p.60-67, 2007.http://www.scielo.br/scielo.php?script=sci_ arttext\&pid $=$ S0101-31222007000200009\&lang $=$ pt

BRASIL. Ministério da Agricultura Pecuária e Abastecimento. Regras para análise de sementes. Ministério da Agricultura, Pecuária e Abastecimento. Secretaria de Defesa Agropecuária. Brasília: MAPA/ACS, 2009. 395p. http:// www.agricultura.gov.br/arq_editor/file/2946_regras_analise_sementes.pdf

CALDWELL, C.R.; BRITZ, S.J.; MIRECKI, R.M. Effect of temperature, elevated carbon dioxide, and drought during seed development on the isoflavone content of dwarf soybean [Glycine max (L.) Merrill] grown in controlled environments. Journal of Agricultural and Food Chemistry, v.53, n.4, p.1125-1129, 2005. http://www.scopus.com/record/display.url?eid=2-s2.0-13944250938\&origin=resultslist\&sort $=$ plf $-\mathrm{f} \& \mathrm{src}=\mathrm{s} \& \mathrm{st} 1=$ Effect + of + Temperature $\% 2 \mathrm{cElevated}+-$ Carbon+Dioxide\&sid=737D6E4D635DF57E4BF78BD960F1C986. WlW7NKKC52nnQNxjqAQrlA\%3a240\&sot=b\&sdt=b\&sl=52\&s=TITLE\%28Effect+of+Temperature\%2cElevated+Carbon+Dioxide $\% 29 \&$ relpos $=16 \&$ relpos $=16 \&$ citeCnt $=64 \&$ searchTerm $=$ TITLE $\% 28$ Effect + of + Temperature $\% 2$ CElevated + Carbon + Dioxide $\% 29$

CAMPANHARO, M.; RODRIGUES, J.J.V.; LIRAJÚNIOR, M.; ESPINDULA, M.C.; COSTA, J.V.T. Características físicas de diferentes substratos para produção de mudas de tomateiro. Revista Caatinga, v.19, n.2, p.140-145, 2006. http://200.137.6.4/revistas/index.php/sistema/article/download/33/31

CHEN, Y.G.; BURRIS, J.S. Role of carbohydrate in desiccation tolerance and membrane behavior in maturing maize seed. Crop Science, v.30, n.3, p.971-975, 1990. https://dl.sciencesocieties.org/publications/cs/abstracts/30/5/ CS0300050971

CONTREIRAS RODRIGUES, A.P.A.; LAURA, V.A.; PEREIRA, S.R.; FERREIRA, E.; FREITAS, M.E. Armazenamento de sementes de salsa osmocondicionadas. Ciência Rural, v. 41, n. 6, p. 978-983, 2011. http://www. scielo.br/pdf/cr/v41n6/a1311cr4324.pdf

COSTA, E.; PEGORARE, A.B.; LEAL, P.A.M.; ESPÍNDOLA, J.S.; SALAMENE, L.C.P. Formação de mudas e produção de frutos de berinjela. Cientifica, v.40, n.1, p.12-20, 2012. http://cientifica.org.br/index.php/ cientifica/article/view/304/pdf

FRANCA, L.V.; CRODA, M.D.; NASCIMENTO, W.M.; FREITAS, R.A. Physiological quality of eggplant seeds with different extraction and drying methods. Journal of Seed Science, v.35, n.1, p.51-55, 2013.http://www.scielo. br/scielo.php?pid=S2317-15372013000100007\&script=sci_arttext 
HOLBIG, L.S.; BAUDET, L.; VILLELA, F.A. Hidrocondicionamento de sementes de cebola. Revista Brasileira de Sementes, v.33, n.1, p.171176, 2011. http://www.scielo.br/scielo.php?script=sci_arttext\&pid=S0101$31222011000100019 \&$ lang $=p t$

HOLBIG, L.S.; BAUDET, L.; VILLELA, F.A.; CAVALHEIRO, V. Recobrimento de sementes de cenoura osmocondicionadas. Revista Brasileira de Sementes, v.32, n.4, p.22-28, 2010. http://www.scielo.br/scielo. php?script=sci_arttext\&pid=S0101-31222010000400003\&lang=pt

KUNKUR, V.; HUNJE, R.; BIRADAR PATIL, N.K.; VYAKARNHAL, B.S. Effect of seed coating with polymer, fungicide and insecticide on seed quality in cotton during storage. Journal of Agricultural Sciences, v.20, n.1, p.137-139, 2007. http://203.129.218.157/ojs/index.php\%20/kjas/article/viewFile/42/42

MAGUIRE, J.D. Speed of germination-aid in selection and evaluation for seedling emergence and vigor. Crop Science, v.2, n.1, p.176-177, 1962. https:// dl.sciencesocieties.org/publications/cs/pdfs/2/2/CS0020020176

MEDEIROS, E.M.; BAUDET, L.; PERES, W.B.; PESKE, F.B. Recobrimento de sementes de cenoura com aglomerante em diversas proporções e fungicida. Revista Brasileira de Sementes, v.28, n.3, p.94-100, 2006. http://www.scielo. br/scielo.php?script=sci_arttext\&pid=S0101-31222006000300014\&lang=pt

NASCIMENTO, W.M. Condicionamento osmótico de sementes de hortaliças visando a germinação em condições de temperaturas baixas. Horticultura Brasileira, v.23, n.2, p.211-214, 2005a. http://www.scielo.br/scielo. php?script=sci_arttext\&pid=S0102-05362005000200010\&lang=pt

NASCIMENTO, W.M. Produção de sementes de hortaliças para a agricultura familiar. Brasília: Embrapa Hortaliças, 2005, p.7-14 (Embrapa Hortaliças. Circular Técnica, 35), 2005b. http://bbeletronica.cnph.embrapa. br/2005/ct/ct_35.pdf

NI, B.R.; BIDDLE, A.J. Alleviation of seed imbibitional chilling injury using polymer film coating: seed treatment challenges and opportunities: proceedings of an international symposium. Bristish Crop Protection Council, v.13, p.73-80, 2001. http://www.cabdirect.org/abstracts/20023014708.html
OLIVEIRA, J.A.; GUIMARÃES, R.M.; ROSA, S.D.V.F. Processamento de sementes pós-colheita. Informe Agropecuário, v.27, n.232, p.52-58, 2006.

PIRES, L.L.; BRAGANTINI, C.; COSTA, J.L.S. Armazenamento de sementes de feijão revestidas com polímeros e tratadas com fungicidas. Pesquisa Agropecuária Brasileira, v.39, n.7, p.709-715, 2004. http://www. scielo.br/pdf/pab/v39n7/21314.pdf

RIBEIRO, C.S.C. Berinjela (Solanum melongena L.). Brasília: EMBRAPA Hortaliças, 2007. <http://sistemasdeproducao.cnptia.embrapa.br/FontesHTML/ Beringela/Beringela_Solanum_melongena_L/>. Acessed on: Nov.1 $18^{\text {th }} .2013$.

SILVA, T.T.A.; OLIVEIRA, J.A.; CARVALHO, M.L.M.; VIEIRA, A.R.; COSTA, R. R.; ABREU, L.A.S. Teor de água na colheita e temperatura de secagem na qualidade de sementes de sorgo, durante o armazenamento. Revista Brasileira de Milho e Sorgo, v.10, n.1, p.66-81, 2011. http://rbms. cnpms.embrapa.br/index.php/ojs/article/view/317/430

SINICIO, R.; BHERING, M.C.; VIDIGAL, D.S.; DIAS, D.C.F.S. Validação do aplicativo computacional Seedsolve para previsão das perdas de germinação e vigor de sementes armazenadas. Revista Brasileira de Sementes, v.31, n.2, p.9-18, 2009. http://www.scielo.br/pdf/rbs/v31n2/v31n2a01

TAYLOR, A.G.; ALLEN, P.S.; BENNETT, M.A.; BRADFORD, K.J.; BURRIS, J.S.; MISRA, M.K. Seed enhancements. Seed Science Research, v.8, n.2, p.245-256, 1998. http://www.scopus.com/record/display.url?eid=2s2.0-0031842997\&origin $=$ resultslist\&zone $=$ contextBox\#

WOOD, C.B.; PRITCHARD, H.W.; AMRITPHALE, D. Desiccation-induced dormancy in papaya (Carica papaya L.) seed is alleviated by heat shock. Seed Science Research, v.10, p.135-145, 2000. http://journals.cambridge.org/ download.php?file=\%2F4128_5D1E6D2C84D69F58EAFFB5BCEAD93B36_ journals__S R _ S S R $10 \_02$ _S 0960258500000143 a . pdf\&cover $=\bar{Y} \&$ code $=2$ f26721d7aab6ec57f $0936 \mathrm{~b} 8 \mathrm{a} 4 \mathrm{~b} 398 \mathrm{c}$ 